\title{
Macronutrient metabolism of adipose tissue at rest and during exercise: a methodological viewpoint
}

\author{
Keith N. Frayn \\ Oxford Lipid Metabolism Group, Radcliffe Infirmary, Oxford OX2 6HE, UK
}

\begin{abstract}
The metabolism of white adipose tissue is regulated by many factors, including hormones and substrates delivered in the blood, the activity of the autonomic nervous system and the rate of flow of blood through the tissue. An integrated view of adipose tissue metabolism can only be gained, therefore, from studies in vivo. Of the various techniques available for studying adipose tissue metabolism in vivo, the measurement of arterio-venous differences offers some unique possibilities. In human subjects this technique has been performed mostly by catheterization of the venous drainage of the subcutaneous abdominal depot. Studies using this technique indicate that adipose tissue has an active pattern of metabolism, responding rapidly to meal ingestion by suppressing the release of non-esterified fatty acids, or to exercise with an increase in fat mobilization. Adipose tissue blood flow may also change rapidly in these situations; for instance, it increases markedly after a meal, potentially increasing the delivery of triacylglycerol to the enzyme lipoprotein lipase (EC 3.1.1.34) for hydrolysis. During exercise, there is evidence that adipose tissue blood flow does not increase sufficiently to allow delivery of all the fatty acids released into the systemic circulation. The various adipose tissue depots have their own characteristic metabolic properties, although in human subjects these are difficult to study with the arterio-venous difference technique. A combination of tracer infusion with selective catheterization allows measurements of leg, splanchnic and non-splanchnic upper-body fat mobilization and triacylglycerol clearance. Development of such techniques may open up new possibilities in the future for obtaining an integrated picture of adipose tissue function and its depot-specific variations.
\end{abstract}

Adipose tissue: Arterio-venous differences: Exercise

Even 5 years ago it was possible to hear an eminent biochemist stand up at a scientific meeting and describe white adipose tissue as rather inert from a metabolic point of view. That view has changed radically over the past few years. Partly, this change has come about because of the recognition of adipose tissue as an important secretory organ, producing not just leptin, a hormone with widespread effects on energy metabolism and other systems (Andrews, 1998), but a whole range of other peptides and biologicallyactive substances with both systemic and autocrine or paracrine effects (Flier, 1995; Sniderman \& Cianflone, 1997; Gregoire et al. 1998). In addition, the plasticity of adipose tissue has been recognized through important new developments in understanding the regulation of adipose tissue gene transcription, and particularly those genes that control adipocyte differentiation and development
(Guerre-Millo et al. 1996; Ailhaud, 1997; Gregoire et al. 1998). But even in the long-recognized area of macronutrient metabolism in white adipose tissue there have been developments. These developments have come about not least because of the development of new and improved techniques for studying this tissue in vivo, in human subjects and other animals (Arner \& Bülow, 1993; Frayn et al. 1997b). A further development has been the recognition that adipose tissue blood flow (ATBF), long considered a potential regulator of metabolism in this tissue (Bülow \& Madsen, 1981), is highly labile and responds rapidly to nutrient ingestion (Bülow et al. 1987; Samra et al. 1995; Summers et al. 1996). The present review will focus on macronutrient metabolism in white adipose tissue, and the methodology used to bring about new insights will be emphasized.

\footnotetext{
Abbreviations: ATBF, adipose tissue blood flow; LPL, lipoprotein lipase; NEFA, non-esterified fatty acids; TG, triacylglycerol. Corresponding author: Dr K.N. Frayn, fax +44 (0)1865 224652, email keith.frayn@ oxlip.ox.ac.uk
} 


\section{Studying adipose tissue metabolism: some methodological considerations}

The study of adipose tissue metabolism reflects one of the triumphs of the reductionist approach. In the 1960s the American Physiological Society published the first comprehensive review of the metabolism of white adipose tissue (Renold \& Cahill, 1965), in which a large proportion of the papers described work done with a particular fat depot of the rat, the epididymal fat pad. The latter preparation has many advantages, not least that it is readily incubated and its metabolism studied in vitro, and that it comes in pairs, so one fat pad can be used as a control while the contralateral pad from the same animal is used for testing different conditions. Rodbell (1964) published the first description of the preparation of isolated adipocytes, by collagenase digestion of the epididymal fat pad. Spherical adipocytes could now be studied in great detail, not least because cells from a number of depots could be pooled to create a uniform suspension, before distributing them amongst several flasks to test the effects of addition of hormones or substrates in different combinations or concentrations. In the past decade or so, adipose tissue has become a model tissue for studying precursor-cell differentiation using modern molecular biological techniques (Guerre-Millo et al. 1996; Ailhaud, 1997; Gregoire et al. 1998).

However, these increasingly refined methods for studying adipose tissue have tended more and more to distract from the important concept that adipose tissue is more than just a collection of adipocytes. It is a highly structured tissue in which vascularization, innervation and cellular arrangement are all important. Some critical metabolic events in adipose tissue take place, not even within or on the surface of the adipocyte, but in the extracellular environment. A clear example is the action of lipoprotein lipase (EC 3.1.1.34; LPL), the enzyme responsible for hydrolysis of triacylglycerol (TG) in the circulating TG-rich lipoprotein particles (chylomicrons and VLDL), which makes fatty acids available for uptake by adipocytes. LPL, although synthesized within adipocytes, is secreted and moves to its site of action, the capillary lumen, where it attaches to endothelial cells via proteoglycan chains and can therefore come into contact with the TG-rich lipoprotein particles, which are largely confined to the vascular space.

It is therefore essential that, alongside these elegant techniques for looking in finer and finer detail at molecular aspects of the adipocyte, we do not lose sight of the need for integrative methods of looking at adipose tissue, which will reflect the complex events governing adipose tissue metabolism in vivo. I have suggested previously that these methods may be grouped under three headings (Frayn et al. 1997b):

(1) systemic tracer techniques (e.g. measurement of the plasma non-esterified fatty acid (NEFA) production rate, which reflects whole-body NEFA release from adipocytes);

(2) microdialysis, enabling the concentrations of (mainly water-soluble) molecules in the interstitial fluid to be measured;

(3) arterio-venous difference methods, enabling quantitative estimates of the flux of metabolites (including
NEFA and TG) to be made, but posing fairly severe anatomical restrictions.

Microdialysis methods have been covered thoroughly in the present symposium by Arner (1999), Bangsbo (1999) and Henriksson (1999). Here I will concentrate on arteriovenous difference measurements. These methods have been reviewed previously (Frayn, 1992; Frayn et al. 1993), but the present review will update those earlier ones. The aim of the following review is to present a picture of adipose tissue metabolism largely, but not exclusively, gained using arterio-venous difference measurements, and with an emphasis on the methodology used.

\section{Outline of macronutrient metabolism in white adipose tissue in relation to the whole body}

White adipose tissue plays an important role in whole-body macronutrient metabolism. This is obvious in view of its unique position as the only tissue able to release NEFA into the circulation. However, the fatty acids that adipose tissue releases have, for the most part, previously been taken up from the circulating TG-rich lipoproteins: chylomicrons (carrying dietary fat) and VLDL (carrying TG secreted from the liver). It is not surprising therefore that adipose tissue also has an important place in the clearance of TG from the plasma, through the activity of the enzyme LPL. The total flux of fatty acids in and out of adipose tissue is difficult to quantify, but the daily flux (in energy equivalents) may be approximately $5 \mathrm{MJ} / \mathrm{d}$ in normal human subjects (Frayn et al. 1995b). Fatty acid flux is substantial in terms of whole-body energy flux, showing that TG and fatty acid metabolism in white adipose tissue are of major importance in whole-body macronutrient metabolism.

NEFA and TG metabolism interact closely in adipose tissue. The action of LPL on the TG-rich lipoproteins generates fatty acids, as does intracellular lipolysis, and the net movement of fatty acids (into adipocytes for esterification and storage in the postprandial state; out of adipocytes for export to the rest of the body during fasting or exercise) is governed by coordinated regulation of the enzymes LPL and hormone-sensitive lipase (EC 3.1.1.3), together with the pathway of fatty acid uptake and esterification. Whilst the whole-body release of NEFA can be studied by measurements of systemic NEFA production rates using isotopic tracers, the greater level of detail that can be uncovered using arterio-venous difference measurements has enabled this picture of fatty acid metabolism to be built up (Frayn et al. 1995a).

Glucose uptake by adipocytes has been studied in detail in isolated or cultured adipocytes in vitro. It is insulin sensitive and is brought about by the insulin-regulated glucose transporter type 4 (GLUT4) with a contribution from glucose transporter type 1 (GLUT 1). However, in vitro studies do not give useful quantitative information on the importance of this process to whole-body glucose utilization. Measurements made by two separate methods in vivo show, however, that glucose uptake by white adipose tissue is not a major pathway in terms of whole-body metabolism. These estimates have been obtained both by arterio-venous difference measurements and also by a 
combination of tracer and biopsy techniques, and they suggest that in lean individuals adipose tissue is responsible for disposal of approximately $4 \%$ (maximum $10 \%$ ) of an oral glucose load (Mårin et al. 1987; Coppack et al. 1990), compared with 30-35\% into skeletal muscle (Coppack et al. 1990; Taylor et al. 1993).

Of the glucose that is taken up, a proportion is oxidized, a proportion released as lactate (and probably as alanine) and a proportion used for synthesis of glycerol-3-phosphate, needed for esterification of fatty acids taken up from the action of LPL. Studies of isolated adipocytes suggest a substantial contribution of anaerobic glycolysis (Mårin et al. 1987; Newby et al. 1988). Estimates in vivo are dependent on the methodology. Arterio-venous difference measurements suggest a much smaller contribution, typically approximately 15-30 \% of the glucose taken up is released as lactate (Frayn et al. 1989; Coppack et al. 1990) and a correspondingly small contribution to whole-body lactate production $(1 \%$ or less of an oral carbohydrate load is released as lactate by adipose tissue; Frayn et al. 1989; Coppack et al. 1990, 1996). However, measurements made by microdialysis suggest much greater lactate production, that may be significant in whole-body terms (Jansson et al. 1994; Simonsen et al. 1994). Estimates of lactate production by the two techniques therefore show a large discrepancy, the reason for which is not understood (Simonsen et al. 1994).

Amino acid metabolism in white adipose tissue is not well understood, although a number of studies both in vitro and in vivo suggest that it is relatively active. In vivo studies have used both microdialysis (Kowalski \& Watford, 1994) and arterio-venous difference measurements (Frayn et al. 1991; Kowalski et al. 1997), and show glutamine release from adipose tissue, along with alanine, at rates that suggest a major role for adipose tissue in whole-body fluxes of these amino acids, and in that of glutamate. Interestingly, some studies of adipocytes in vitro show net utilization of glutamine (Kowalchuk et al. 1988). The reason for the discrepancy is not clear.

A brief description has been given of the major features of white adipose tissue macronutrient metabolism. This alone should be sufficient to counter any description of white adipose tissue as relatively inert in metabolic terms. The complexity of white adipose tissue metabolism in vivo as revealed by arterio-venous difference measurements is illustrated in Fig. 1.

However, the metabolic importance of white adipose tissue is most clearly seen by considering the dynamic changes that occur in response to physiological situations such as fasting and feeding, and exercise.

\section{Macronutrient metabolism of white adipose tissue in fasting and fed states}

In the post-absorptive state fatty acids are a major source of oxidative fuel in the body. These fatty acids arise largely from white adipose tissue, exported in the form of NEFA. Some tissues oxidize fatty acids taken up from circulating VLDL particles by the action of LPL. However, these fatty acids will themselves have come largely from adipose tissue, taken up by the liver and re-esterified into TG for

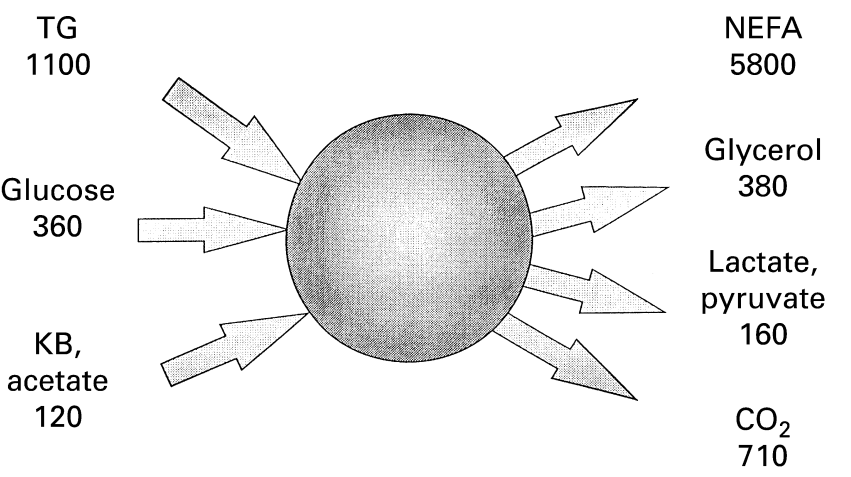

In 1580

Out 7050

Fig. 1. Net uptake and release of various metabolites across human subcutaneous adipose tissue in vivo after an overnight fast, studied by measurement of arterio-venous differences. Values shown are net uptake or release expressed in $\mu \mathrm{g}$ atoms $\mathrm{C} / \mathrm{l}$ whole-blood flow through the tissue: thus, the values indicate relative ' $\mathrm{C}$ atom balance' from the various substrates, the sum of which is also shown. After an overnight fast, adipose tissue is a consistent exporter of $\mathrm{C}$ mainly in the form of non-esterified fatty acids (NEFA). TG, triacylglycerols; KB, ketone bodies. (Drawn from data in Coppack et al. 1990.)

secretion. Thus, in the post-absorptive state white adipose tissue controls the flux of a major oxidative fuel to other tissues in the body.

After feeding, this situation changes rapidly. In the case of a mixed meal containing carbohydrate and fat, exogenous glucose enters the plasma and there is a rapid switch in whole-body fuel economy, so that glucose displaces fatty acids as the major fuel for many tissues, including skeletal muscle (Elia et al. 1988). It is well established that elevated concentrations of fatty acids may impair insulin stimulation of glucose utilization by skeletal and cardiac muscle (Randle et al. 1963; Ferrannini et al. 1983), and therefore it is appropriate that NEFA release from adipose tissue is extremely sensitive to suppression by insulin (Taylor et al. 1984; Jensen et al. 1989; Campbell et al. 1992). In fact NEFA release from adipose tissue changes from its maximal rate in the typical $24 \mathrm{~h}$ cycle to approximately zero within 60-90 min of eating a mixed meal (Coppack et al. 1990, 1992; Fig. 2). At the same time, other processes are stimulated to reverse the net release of fatty acids from adipocytes and begin net uptake of fatty acids for esterification and storage. These processes include the up regulation of LPL by insulin (Sadur \& Eckel, 1982; Ong \& Kern, 1989) and perhaps by gut hormones (Oben et al. 1992). However, possibly the most important change is the stimulation of fatty acid esterification in adipocytes, brought about by insulin (Leboeuf, 1965; Frayn et al. 1994) and by acylation-stimulating protein (Sniderman \& Cianflone, 1997; Sniderman et al. 1997). Acylation-stimulating protein is a peptide, identical to C3a-desarg, a product of the alternative complement pathway, that is produced locally in adipose tissue and feeds back to stimulate fatty acid esterification. Its production is stimulated by the presence of chylomicrons (carrying dietary fat), thus leading to close coordination of metabolic events in adipose tissue in the postprandial period (Maslowska et al. 1997). 


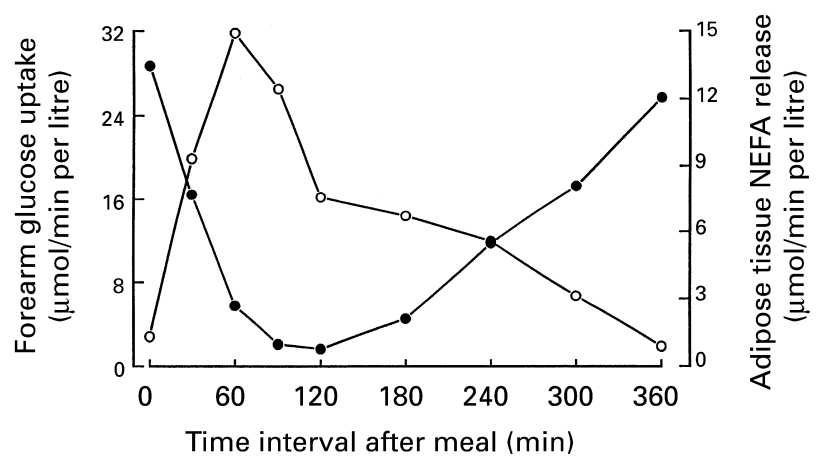

Fig. 2. Suppression of non-esterified fatty acid (NEFA) release from subcutaneous adipose tissue after ingestion of a mixed meal in normal subjects $(\bullet)$, compared with the simultaneous stimulation of forearm glucose uptake $(O)$, both assessed by measurements of arterio-venous differences together with blood flow rates. Values at time zero were obtained after an overnight fast. Adipose tissue NEFA release changes from its highest value in the $24 \mathrm{~h}$ cycle to virtually zero within $2 \mathrm{~h}$. (Based on data from Coppack et al. 1996 and Frayn et al. 1996b; reproduced, with permission, from Frayn \& Summers, 1998.)

Measurement of arterio-venous differences has allowed the construction of this dynamic view of the regulation of adipose tissue metabolism in the post-absorptive-postprandial transition. Tracer methods for measuring NEFA production rates can give useful information in the nonsteady-state such as that following meal ingestion (Jensen et al. 1990), but measurement of arterio-venous differences for NEFA, TG and glycerol has enabled the integration of NEFA and TG metabolism to be studied during this phase (Frayn et al. 1995b). The secretion of acylation-stimulating protein by adipose tissue, coordinated with postprandial TG metabolism, has also been demonstrated using this technique (Saleh et al. 1998). The use of arterio-venous difference measurements in the non-steady-state may itself pose problems (Zierler, 1961), but it has been argued that these problems may not be as severe as sometimes claimed (Elia et al. 1988).

\section{Potential role of blood flow as a regulator of white adipose tissue metabolism}

It will be clear from the earlier discussion that the major metabolic exchanges between adipose tissue and blood are of the hydrophobic molecules NEFA (bound to albumin), and TG carried in the TG-rich lipoproteins. These substances, unlike small hydrophilic molecules such as glucose and glycerol, cannot diffuse readily through interstitial fluid. It is not surprising therefore that white adipose tissue is relatively well vascularized; the number of capillaries per unit cytoplasm is typically greater than in skeletal muscle (Frayn \& Macdonald, 1996). Furthermore, ATBF is highly variable according to physiological state (Frayn \& Macdonald, 1996; Frayn et al. 1997a). The close connections between adipose tissue metabolism and ATBF have been reviewed previously (Crandall \& DiGirolamo, 1990; Frayn \& Macdonald, 1996; Frayn et al. 1997a). In brief, it seems that ATBF always increases in parallel with stimulation of fat mobilization. This relationship is intuitively reasonable since increased ATBF is needed to transport the product of lipolysis (NEFA) away from the tissue. The coordination of ATBF and stimulation of lipolysis (measured using arterio-venous differences) is illustrated in Fig. 3. More recently we have come to appreciate that ATBF also increases in the postprandial period (Coppack et al. 1992; Samra et al. 1995; Summers et al. 1996), and we have argued (Frayn et al. 1997a) that this increase may represent the need to deliver substrate (TG in the chylomicrons) to adipose tissue LPL for rapid clearance. Indeed, in an experiment in which ATBF was increased by infusion of adrenaline, local TG clearance measured using arterio-venous differences increased in parallel with ATBF, suggesting that it may normally be flow limited (Samra et al. 1996). The potential role of ATBF in limiting metabolism will be further discussed in connection with exercise (see pp. 881-882).

\section{Regional variations in adipose tissue macronutrient metabolism}

It has become clear in recent years that the various discrete adipose depots have their individual metabolic characteristics. These observations have been prompted by the association between fat distribution, insulin resistance and cardiovascular risk factors, with an excess accumulation of fat in the upper body or abdominal region associated with increased risk of development of type 2 diabetes and of CHD (Björntorp, 1991). A brief summary is that the lowerbody (gluteal and femoral) adipose depots are characterized by a relatively sluggish pattern of metabolism, responding less than other depots to lipolytic stimulation (Arner et al. 1990). The subcutaneous abdominal adipose tissue has an intermediate metabolic activity, and intra-abdominal depots have the most active pattern of metabolism (Rebuffé-Scrive et al. 1987, 1989, 1990; Richelsen et al. 1991; Arner, 1995). The mechanisms involve differences in receptor density and function (sensitivity to stimulation) in the different depots (Vikman et al. 1991; Arner, 1995; Hoffstedt et al. 1997).

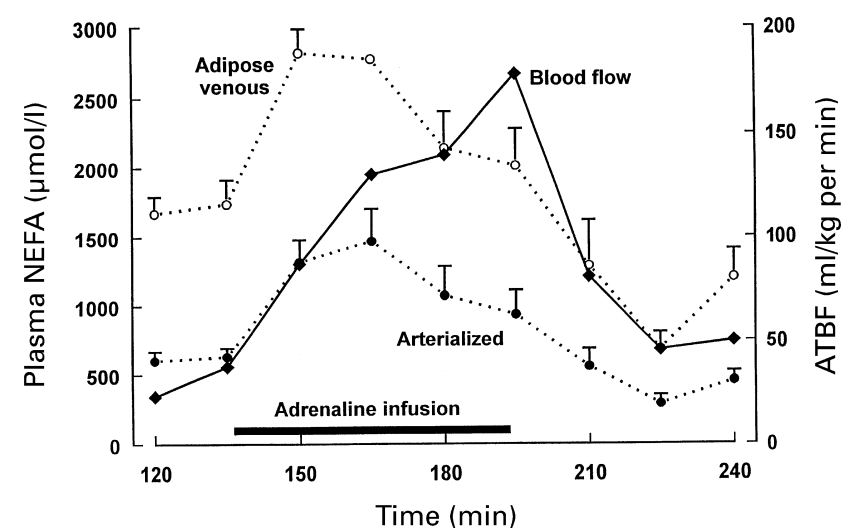

Fig. 3. Effects of adrenaline infusion ( $25 \mathrm{ng} / \mathrm{kg}$ per $\mathrm{min}$ ) on adipose tissue blood flow (ATBF, $\bullet \bullet)$, and on arterialized $(\bullet \cdots \cdots \cdot)$ ) and adipose tissue venous $(\bigcirc \cdots \cdots . . \circ)$ non-esterified fatty acid (NEFA) concentrations, in six normal subjects. As the NEFA concentration in the venous plasma approached $3 \mathrm{mmol} / \mathrm{l}$, so increased blood flow prevented a further increase despite continued NEFA efflux at a high rate. (Based on Samra et al. 1996 reproduced, with permission, from Frayn et al. 1997a.) 
The receptors involved include adrenergic $\beta$-receptors stimulating lipolysis, and insulin and adenosine receptors suppressing it. The hypothesis has been advanced that the intra-abdominal depots, some of which discharge the products of lipolysis directly into the portal vein, have direct effects on hepatic metabolism. In particular, it is envisaged that a high flux of NEFA from omental adipose tissue will drive VLDL-TG secretion, stimulate hepatic glucose production and potentially decrease hepatic insulin clearance (Björntorp, 1994; Arner, 1997), the so-called 'portal theory' (Arner, 1997).

It is wise to remember, however, that these observations are to a large extent based on studies of isolated explants of adipose tissue or isolated adipocytes, and caution must be exercised, as discussed earlier, before extrapolating such observations to the situation in vivo. Microdialysis can be used to sample interstitial glycerol concentrations in different subcutaneous depots (although not intra-abdominal depots) and such studies confirm the greater metabolic lability of abdominal $v$. gluteal fat (Arner et al. 1990). Arterio-venous difference measurements should provide an ideal method for confirmation, or otherwise, of these observations in vivo. However, they are difficult to perform for anatomical reasons. Confirmation of the portal theory really requires sampling from the portal vein, which is difficult in human subjects, although it has been performed in a small number of studies (usually at laparotomy). The results of these studies have been reviewed in more detail by Frayn et al. (1997c), but they do not generally confirm the idea of a high concentration of NEFA (or glycerol) in the portal vein compared with other sites.

An alternative approach is to use combined tracer infusion and arterial-hepatic venous sampling to assess arterio-venous differences across the splanchnic bed. If it is assumed that the liver does not release glycerol or NEFA, then any dilution of labelled fatty acids or glycerol observed across the splanchic bed may be presumed to reflect lipolysis in splanchnic adipose tissue. Such studies, using either labelled fatty acids or glycerol, do show some dilution of label, but the rate of lipolysis in splanchnic adipose tissue estimated in this way appears small in relation to that in the whole body. Nevertheless, it must be remembered that the products of this lipolytic process are delivered directly to the liver and so, as discussed earlier, may have a metabolic impact greater than their absolute amount might suggest.

Recent studies from Jensen and colleagues (Jensen \& Johnson, 1996; Nguyen et al. 1996) have brought new methodology to bear on this issue. They combine selective catheterization of the femoral and hepatic veins, providing information on lower-body (leg) and splanchnic bed fat metabolism. Concomitant infusion of a radio-labelled fatty acid tracer allows the calculation of whole-body, leg and splanchnic rates of release and uptake of fatty acids. Splanchic NEFA release is assumed to arise from intraabdominal adipose tissue. By subtraction, the rate of NEFA release from non-splanchnic upper-body adipose tissue can be calculated. Regional clearance of meal-derived fatty acids from chylomicron TG can be estimated in a similar way. These studies show a large clearance of meal-derived fatty acids in the splanchnic bed in men, although less in women, perhaps supporting the observation that men tend to accumulate fat in this depot more than women (Nguyen et al. 1996). In the post-absorptive state, splanchnic NEFA release contributed $15-16 \%$ of the total systemic NEFA release, leg adipose tissue 24-30 \%, and upper-body nonsplanchnic adipose tissue (by subtraction) contributed the majority of systemic NEFA release (61-66 \%; Jensen \& Johnson, 1996). Thus, the idea of substantial metabolic activity of splanchnic adipose tissue (especially in men) is sustained, although the surprising finding is the relative importance of the upper-body non-splanchnic adipose tissue.

\section{Adipose tissue metabolism during exercise}

Plasma NEFA form the major energy source for exercise of low intensity or long duration (Coyle, 1995). Thus, there must be coordination of adipose tissue NEFA release and metabolic energy demand. This coordination is probably mediated mainly by adrenergic mechanisms. If propranolol, a $\beta$-adrenergic blocker, is introduced locally into subcutaneous adipose tissue, the stimulation of lipolysis during exercise is markedly reduced (Arner et al. 1990) and systemic $\beta$-adrenergic blockade lowers glycerol and NEFA concentrations during exercise (Wijnen et al. 1993). Stimulation of lipolysis may be reinforced by the gradual fall in plasma insulin concentration during strenuous exercise, and by the increased plasma concentrations of cortisol and growth hormone (Hodgetts et al. 1991). These stimuli are all known to increase lipolysis at rest, but their importance during exercise is not known.

The contribution that selective catheterization methods have made to studying fat metabolism during exercise has been summarized previously (Frayn et al. 1996a). These studies include arterio-venous difference measurements across muscle beds (both resting and exercising) and across the splanchnic bed, as well as across subcutaneous adipose tissue. Measurements across adipose tissue have shed some light on factors regulating NEFA release during exercise (Hodgetts et al. 1991).

The increase in adipose tissue lipolysis during exercise can be demonstrated in a number of ways. It has been shown by an increase in interstitial glycerol concentration in subcutaneous adipose tissue during exercise (Arner et al. 1990). There is an increased systemic glycerol production rate (Jones et al. 1980; Wolfe et al. 1990; Romijn et al. 1993), taken to imply an increase in whole-body lipolysis, of which adipose tissue lipolysis is likely to be a major component. The rate of appearance of plasma NEFA also increases (Wolfe et al. 1990; Romijn et al. 1993). However, the systemic plasma NEFA concentration may not rise as much as the rate of appearance, leading to dissociation of the normal close relationship between NEFA production rate and systemic NEFA concentration. NEFA concentrations in the venous drainage from subcutaneous adipose tissue increase much more than those in systemic plasma, implying that there is rapid utilization, presumably by the working muscle (Hodgetts et al. 1991).

NEFA released from adipose tissue may be oxidized in other tissues, or they may be re-esterified. This reesterification may be local within the same depot (perhaps even within the adipocyte) or it may occur in other tissues. 
The whole-body re-esterification of fatty acids falls dramatically during exercise (Wolfe et al. 1990), so leaving more fatty acids for oxidation. This situation is also true within adipose tissue; the proportion of fatty acids re-esterified within adipose tissue (estimated using arterio-venous difference measurements of NEFA:glycerol release) decreases to approximately zero during $1 \mathrm{~h}$ of exercise at 50-70 \% of maximum $\mathrm{O}_{2}$ uptake (Hodgetts et al. 1991). However, these calculations may be misleading (see discussion below); the fatty acids retained in adipose tissue may be retained in a non-esterified form.

ATBF usually increases when lipolysis is increased, as discussed previously. Since $\beta$-adrenergic stimulation itself has vasodilator effects in adipose tissue (Hjemdahl \& Linde, 1983; Simonsen et al. 1990), it might be expected that ATBF would increase during exercise. In fact there are few findings to suggest this increase occurs. Bülow \& Madsen (1976, 1978) showed large increases in ATBF during prolonged moderate-intensity exercise (50\% maximum $\mathrm{O}_{2}$ uptake), manifest during the first hour but increasing substantially with further 50 min periods of exercise (Fig. 4). Other studies, however, have failed to show this increase in ATBF (Frid et al. 1990; Hellström et al. 1996). It could be argued that in heavy exercise so much of cardiac output is diverted to the working muscles that there is little left to increase ATBF. This situation would parallel the fall in splanchnic blood flow during strenuous exercise, which may limit the contribution of hepatic gluconeogenesis to substrate supply (Fojt et al. 1976). Even in the study of Bülow \& Madsen (1976) it can be argued that ATBF did not increase to match the increased need for delivery of NEFA to the circulation (Fig. 4). The validity of this argument becomes very clear when rates of NEFA release are examined at different exercise intensities; the rate of appearance of NEFA actually falls as exercise

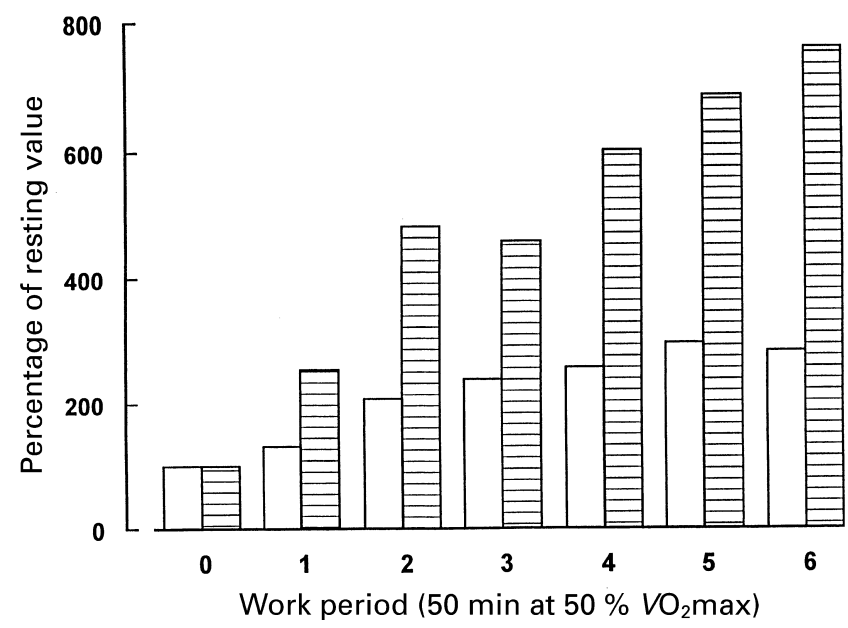

Fig. 4. Relative changes in adipose tissue blood flow (ATBF; $\square$ ) and systemic non-esterified fatty acids (NEFA) concentrations ( $\equiv$ ) during prolonged exercise in healthy men. Values are expressed as a percentage of the value in the resting state (period 0). Each successive work period was of 50 min duration at an intensity of $50 \%$ maximum $\mathrm{O}_{2}$ uptake $\left(\mathrm{VO}_{2} \mathrm{max}\right)$. Although ATBF increases substantially, it does not increase as much as systemic plasma NEFA concentrations; hence, it could be argued that the increase in ATBF is not appropriately large for the increase in lipolysis. (Data taken from Bülow \& Madsen, 1976.) intensity increases from light to heavy (Jones et al. 1980; Romijn et al. 1993). Since the stimuli to lipolysis are all likely to increase in relation to the intensity of exercise, this finding presumably reflects insufficiency of ATBF to deliver all the NEFA that might be released in lipolysis into the circulation. In fact, during heavy exercise, the relative rates of appearance of glycerol and NEFA show that lipolysis occurs but does not lead to release of NEFA into the plasma (Jones et al. 1980). This view is confirmed by the sudden release of NEFA, without accompanying glycerol, at the end of exercise (Hodgetts et al. 1991; Romijn et al. 1993). However, arterio-venous difference measurements across subcutaneous adipose tissue have not been performed at different intensities of exercise, and so the potential of this technique to demonstrate more clearly the entrapment of fatty acids in adipose tissue during highintensity exercise has not yet been exploited. In part this situation reflects the technical difficulties of these measurements.

\section{Critical review of methodology}

The arterio-venous difference technique for studying macronutrient metabolism in adipose tissue has allowed a dynamic picture of adipose tissue metabolism and its regulation in different physiological states to be built up. The technique has been applied in a number of species, including dog (Bülow et al. 1985; Holloway et al. 1985), fat-tailed sheep (Gooden et al. 1986), rat (Kowalski et al. 1997) and human subjects (Frayn et al. 1989). This technique allows the quantitative estimation of net substrate fluxes. When combined with tracer infusions this technique may allow calculations of absolute uptake and release rates (Kurpad et al. 1994). In many cases qualitatively similar information is gained from microdialysis and arterio-venous difference techniques (Simonsen et al. 1994; Kowalski et al. 1997; Summers et al. 1998), but quantitative estimates of substrate flux do not always agree as well (Simonsen et al. 1994; Summers et al. 1998).

Some limitations of the arterio-venous difference technique must be borne in mind. First, because of anatomical limitations, its use in human subjects is probably restricted to the anterior abdominal subcutaneous adipose depot. There is evidence that in terms of NEFA release this depot behaves typically of all the adipose tissue that contributes to the systemic plasma NEFA concentration (Frayn et al. 1993). Second, catheterization of the venous drainage of adipose tissue is technically difficult, and even with experience success rates never exceed about $80 \%$. Some experiments are therefore wasted, especially in experimental designs that require subjects to return on more than one occasion. There is limited experience of using this technique during exercise. Our own experience shows that this is possible, but again technically difficult (Hodgetts et al. 1991). It has not been used at intensities greater than $70 \%$ maximum $\mathrm{O}_{2}$ uptake and our limited experience suggests this would be very difficult (but not necessarily impossible).

An alternative approach, combining tracer methods for measuring absolute rates of NEFA uptake and release with selective catheterization, has recently been developed. This 
approach allows assessment of regional NEFA production and utilization rates (leg, upper-body non-splanchnic and splanchnic; Jensen \& Johnson, 1996; Nguyen et al. 1996), and is a useful complement to the anatomically-stricter catheterization of subcutaneous abdominal adipose tissue venous drainage.

\section{Conclusion}

White adipose tissue is an important site of macronutrient metabolism, both in its own right, and as the supplier of NEFA to other tissues. We now recognize white adipose tissue to have an extremely active and highly regulated pattern of metabolism, which complements its role as a secretory organ, particularly in relation to the production of leptin which itself is a major controller of macronutrient metabolism. New techniques have made the study of adipose tissue metabolism in vivo feasible, and thus helped to highlight its metabolic importance, especially the techniques of microdialysis and arterio-venous difference measurement. The regulation of ATBF is intimately linked with macronutrient metabolism in adipose tissue.

\section{Acknowledgements}

I would like to thank my many colleagues, past and present, in Oxford who have helped to shape these views and have provided the data on which they are based, especially Simon Coppack, Barbara Fielding, Vanessa Hodgetts, Sandy Humphreys, Jas Samra and Lucinda Summers. I would also like to thank Peter Arner, Jens Bülow and Ian Macdonald, who have been collaborators in some of this work.

\section{References}

Ailhaud G (1997) Molecular mechanisms of adipocyte differentiation. Journal of Endocrinology 155, 201-202.

Andrews JF (1998) Leptin: energy regulation and beyond to a hormone with pan-physiological function. Proceedings of the Nutrition Society 57, 409-411.

Arner P (1995) Differences in lipolysis between human subcutaneous and omental adipose tissues. Annals of Medicine 27, 435-438.

Arner P (1997) Impact of visceral fat. International Journal of Obesity 21, Suppl. 2, S20.

Arner P (1999) Microdialysis: use in human exercise studies. Proceedings of the Nutrition Society 58, 913-917.

Arner P \& Bülow J (1993) Assessment of adipose tissue metabolism in man: comparison of Fick and microdialysis techniques. Clinical Science 85, 247-256.

Arner P, Kriegholm E, Engfeldt P \& Bolinder J (1990) Adrenergic regulation of lipolysis in situ at rest and during exercise. Journal of Clinical Investigation 85, 893-898.

Bangsbo J (1999) Vasoactive substances in the interstitium of contracting muscle examined by microdialysis. Proceedings of the Nutrition Society 58, 925-933.

Björntorp P (1991) Metabolic implications of body fat distribution. Diabetes Care 14, 1132-1143.

Björntorp P (1994) Fatty acids, hyperinsulinemia, and insulin resistance: which comes first? Current Opinion in Lipidology $\mathbf{5}$, 166-174.

Bülow J, Astrup A, Christensen NJ \& Kastrup J (1987) Blood flow in skin, subcutaneous adipose tissue and skeletal muscle in the forearm of normal man during an oral glucose load. Acta Physiologica Scandinavica 130, 657-661.

Bülow J \& Madsen J (1976) Adipose tissue blood flow during prolonged, heavy exercise. Pflügers Archiv 363, 231-234.

Bülow J \& Madsen J (1978) Human adipose tissue blood flow during prolonged exercise II. Pflügers Archiv 376, 41-45.

Bülow J \& Madsen J (1981) Influence of blood flow on fatty acid mobilization from lipolytically active adipose tissue. Pflügers Archiv 390, 169-174.

Bülow J, Madsen J, Astrup A \& Christensen NJ (1985) Vasoconstrictor effect of high FFA/albumin ratios in adipose tissue in vivo. Acta Physiologica Scandinavica 125, 661-667.

Campbell PJ, Carlson MG, Hill JO \& Nurjhan N (1992) Regulation of free fatty acid metabolism by insulin in humans: role of lipolysis and reesterification. American Journal of Physiology 263, E1063-E1069.

Coppack SW, Evans RD, Fisher RM, Frayn KN, Gibbons GF, Humphreys SM, Kirk MJ, Potts JL \& Hockaday TDR (1992) Adipose tissue metabolism in obesity: lipase action in vivo before and after a mixed meal. Metabolism 41, 264-272.

Coppack SW, Fisher RM, Gibbons GF, Humphreys SM, McDonough MJ, Potts JL \& Frayn KN (1990) Postprandial substrate deposition in human forearm and adipose tissues in vivo. Clinical Science 79, 339-348.

Coppack SW, Fisher RM, Humphreys SM, Clark ML, Pointon JJ \& Frayn KN (1996) Carbohydrate metabolism in insulin resistance: glucose uptake and lactate production by adipose and forearm tissues in vivo before and after a mixed meal. Clinical Science $\mathbf{9 0}$, $409-415$.

Coppack SW, Frayn KN, Humphreys SM, Whyte PL \& Hockaday TDR (1990) Arteriovenous differences across human adipose and forearm tissues after overnight fast. Metabolism 39, 384-390.

Coyle EF (1995) Substrate utilization during exercise in active people. American Journal of Clinical Nutrition 61, Suppl., 968S-979S

Crandall DL \& DiGirolamo M (1990) Hemodynamic and metabolic correlates in adipose tissue: pathophysiologic considerations. FASEB Journal 4, 141-147.

Elia M, Folmer P, Schlatmann A, Goren A \& Austin S (1988) Carbohydrate, fat, and protein metabolism in muscle and in the whole body after mixed meal ingestion. Metabolism 37, 542-551.

Ferrannini E, Barrett EJ, Bevilacqua S \& DeFronzo RA (1983) Effect of fatty acids on glucose production and utilization in man. Journal of Clinical Investigation 72, 1737-1747.

Flier JS (1995) The adipocyte: Storage depot or node on the energy information superhighway? Cell 80, 15-18.

Fojt E, Ekelund LG \& Hultman E (1976) Enzyme activities in hepatic venous blood under strenuous physical exercise. Pfügers Archiv 361, 287-296.

Frayn KN (1992) Studies of human adipose tissue in vivo. In Energy Metabolism: Tissue Determinants and Cellular Corollaries, pp. 267-295 [JM Kinney and HN Tucker, editors]. New York: Raven Press.

Frayn KN, Coppack SW, Fielding BA \& Humphreys SM (1995a) Coordinated regulation of hormone-sensitive lipase and lipoprotein lipase in human adipose tissue in vivo: implications for the control of fat storage and fat mobilization. Advances in Enzyme Regulation 35, 163-178.

Frayn KN, Coppack SW \& Humphreys SM (1993) Subcutaneous adipose tissue metabolism studied by local catheterization. International Journal of Obesity 17, Suppl. 3, S18-S21.

Frayn KN, Coppack SW, Humphreys SM \& Whyte PL (1989) Metabolic characteristics of human adipose tissue in vivo. Clinical Science 76, 509-516. 
Frayn KN, Fielding BA, Samra JS \& Summers LKM (1997a) Extracellular metabolic regulation in adipose tissue. In Physiology, Stress, and Malnutrition, pp. 303-323 [JM Kinney and HN Tucker, editors]. Philadelphia, PA: Lippincott-Raven.

Frayn KN, Fielding BA \& Summers LKM (1997b) Investigation of human adipose tissue metabolism in vivo. Journal of Endocrinology 155, 187-189.

Frayn KN, Hodgetts V \& Griffiths AJ (1996a) Mobilization and clearance of fat in exercising humans studied by regional venous catheterization. In Biochemistry of Exercise, vol. 9, pp. 73-88 [RJ Maughan and SM Shirreffs, editors]. Champaign, IL: Human Kinetics.

Frayn KN, Humphreys SM \& Coppack SW (1995b) Fuel selection in white adipose tissue. Proceedings of the Nutrition Society 54, 177-189.

Frayn KN, Humphreys SM \& Coppack SW (1996b) Net carbon flux across subcutaneous adipose tissue after a standard meal in normal-weight and insulin-resistant obese subjects. International Journal of Obesity 20, 795-800.

Frayn KN, Khan K, Coppack SW \& Elia M (1991) Amino acid metabolism in human subcutaneous adipose tissue in vivo. Clinical Science 80, 471-474.

Frayn KN \& Macdonald IA (1996) Adipose tissue circulation. In Nervous Control of Blood Vessels, pp. 505-539 [T Bennett and SM Gardiner, editors]. Amsterdam: Harwood Academic.

Frayn KN, Samra JS \& Summers LKM (1997c) Visceral fat in relation to health: is it a major culprit or simply an innocent bystander? International Journal of Obesity 21, 1191-1192.

Frayn KN, Shadid S, Hamlani R, Humphreys SM, Clark ML, Fielding BA, Boland O \& Coppack SW (1994) Regulation of fatty acid movement in human adipose tissue in the postabsorptive-to-postprandial transition. American Journal of Physiology 266, E308-E317.

Frayn KN \& Summers LKM (1998) Substrate fluxes in skeletal muscle and white adipose tissue and their importance in the development of obesity. In Clinical Obesity, pp. 129-157 [PG Kopelman and MJ Stock, editors]. Oxford: Blackwell Science.

Frid A, Östman J \& Linde B (1990) Hypoglycemia risk during exercise after intramuscular injection of insulin in thigh in IDDM. Diabetes Care 13, 473-477.

Gooden JM, Campbell SL \& van der Walt JG (1986) Measurement of blood flow and lipolysis in the hindquarter tissues of the fat-tailed sheep in vivo. Quarterly Journal of Experimental Physiology 71, 537-547.

Gregoire FM, Smas CM \& Sul HS (1998) Understanding adipocyte differentiation. Physiological Reviews 78, 783-809.

Guerre-Millo M, Staels B \& Auwerx J (1996) New insights into obesity genes. Diabetologia 39, 1528-1531.

Hellström L, Blaak E \& Hagström-Toft E (1996) Gender differences in adrenergic regulation of lipid mobilization during exercise. International Journal of Sports Medicine 17, 439-447.

Henriksson J (1999) Microdialysis of skeletal muscle at rest. Proceedings of the Nutrition Society 58, 919-923.

Hjemdahl P \& Linde B (1983) Influence of circulating NE and Epi on adipose tissue vascular resistance and lipolysis in humans. American Journal of Physiology 245, H447-H452.

Hodgetts V, Coppack SW, Frayn KN \& Hockaday TDR (1991) Factors controlling fat mobilization from human subcutaneous adipose tissue during exercise. Journal of Applied Physiology 71, 445-451.

Hoffstedt J, Arner P, Hellers G \& Lonnqvist F (1997) Variation in adrenergic regulation of lipolysis between omental and subcutaneous adipocytes from obese and non-obese men. Journal of Lipid Research 38, 795-804.

Holloway BR, Stribling D, Freeman S \& Jamieson L (1985) The thermogenic role of adipose tissue in the dog. International Journal of Obesity 9, 423-432.
Jansson P-A, Larsson A, Smith U \& Lönnroth P (1994) Lactate release from the subcutaneous tissue in lean and obese men. Journal of Clinical Investigation 93, 240-246.

Jensen MD, Caruso M, Heiling V \& Miles JM (1989) Insulin regulation of lipolysis in nondiabetic and IDDM subjects. Diabetes 38, 1595-1601.

Jensen MD, Heiling V \& Miles JM (1990) Measurement of nonsteady-state free fatty acid turnover. American Journal of Physiology 258, E103-E108.

Jensen MD \& Johnson CM (1996) Contribution of leg and splanchnic free fatty acid (FFA) kinetics to postabsorptive FFA flux in men and women. Metabolism 45, 662-666.

Jones NL, Heigenhauser GJF, Kuksis A, Matos CG, Sutton JR \& Toews CJ (1980) Fat metabolism in heavy exercise. Clinical Science 59, 469-478.

Kowalchuk JM, Curi R \& Newsholme EA (1988) Glutamine metabolism in isolated incubated adipocytes of the rat. Biochemical Journal 249, 705-708.

Kowalski TJ \& Watford M (1994) Production of glutamine and utilization of glutamate by rat subcutaneous adipose tissue in vivo. American Journal of Physiology 266, E151-E154.

Kowalski TJ, Wu G \& Watford M (1997) Rat adipose tissue amino acid metabolism in vivo as assessed by microdialysis and arteriovenous techniques. American Journal of Physiology 273, E613-E622.

Kurpad A, Khan K, Calder AG, Coppack S, Frayn K, Macdonald I \& Elia M (1994) Effect of noradrenaline on glycerol turnover and lipolysis in the whole body and subcutaneous adipose tissue in humans in vivo. Clinical Science 86, 177-184.

Leboeuf B (1965) Regulation of fatty acid esterification in adipose tissue incubated in vitro. In Handbook of Physiology. Section 5, Adipose Tissue, pp. 385-391 [AE Renold and GF Cahill, editors]. Washington, DC: American Physiological Society.

Mårin P, Rebuffé-Scrive M, Smith U \& Björntorp P (1987) Glucose uptake in human adipose tissue. Metabolism 36, 1154-1160.

Maslowska M, Scantlebury T, Germinario R \& Cianflone K (1997) Acute in vitro production of acylation stimulating protein in differentiated human adipocytes. Journal of Lipid Research 38, $1-11$.

Newby FD, Sykes MN \& DiGirolama M (1988) Regional differences in adipocyte lactate production from glucose. American Journal of Physiology 255, E716-E722.

Nguyen TT, Mijares AH, Johnson CM \& Jensen MD (1996) Postprandial leg and splanchnic fatty acid metabolism in nonobese men and women. American Journal of Physiology 271, E965-E972.

Oben J, Elliott R, Morgan L, Fletcher J \& Marks V (1992) The role of gut hormones in the adipose tissue metabolism of lean and genetically obese $(o b / o b)$ mice. In Obesity in Europe 91. Proceedings of the 3rd European Congress on Obesity, pp. 269-272 [G Ailhaud, B Guy-Grand, M Lafontan and D Ricquier, editors]. London: Libby.

Ong JM \& Kern PA (1989) Effect of feeding and obesity on lipoprotein lipase activity, immunoreactive protein, and messenger RNA levels in human adipose tissue. Journal of Clinical Investigation 84, 305-311.

Randle PJ, Garland PB, Hales CN \& Newsholme EA (1963) The glucose fatty-acid cycle. Its role in insulin sensitivity and the metabolic disturbances of diabetes mellitus. Lancet i, 785-789.

Rebuffé-Scrive M, Anderson B, Olbe L \& Björntorp P (1990) Metabolism of adipose tissue in intraabdominal depots in severely obese men and women. Metabolism 39, 1021-1025.

Rebuffé-Scrive M, Andersson B, Olbe L \& Björntorp P (1989) Metabolism of adipose tisue in intraabdominal depots of nonobese men and women. Metabolism 38, 453-458.

Rebuffé-Scrive M, Lönnroth P, Mårin P, Wesslau C, Björntorp P \& Smith U (1987) Regional adipose tissue metabolism in men and 
postmenopausal women. International Journal of Obesity 11, 347-355.

Renold AE \& Cahill GF (1965) Metabolism of isolated adipose tissue: a summary. In Handbook of Physiology. Section 5, Adipose Tissue, pp. 483-490 [AE Renold and GF Cahill, editors]. Washington, DC: American Physiological Society.

Richelsen B, Pedersen SB, Møller-Pedersen T \& Bak JF (1991) Regional differences in triglyceride breakdown in human adipose tissue: effects of catecholamines, insulin, and prostaglandin $\mathrm{E}_{2}$. Metabolism 40, 990-996.

Rodbell M (1964) Metabolism of isolated fat cells. 1. Effects of hormones on glucose metabolism and lipolysis. Journal of Biological Chemistry 239, 375-380.

Romijn JA, Coyle EF, Sidossis LS, Gastaldelli A, Horowitz JF, Endert E \& Wolfe RR (1993) Regulation of endogenous fat and carbohydrate metabolism in relation to exercise intensity and duration. American Journal of Physiology 265, E380-E391.

Sadur CN \& Eckel RH (1982) Insulin stimulation of adipose tissue lipoprotein lipase. Use of the euglycemic clamp technique. Journal of Clinical Investigation 69, 1119-1125.

Saleh J, Summers L, Cianflone K, Fielding B, Sniderman A \& Frayn K (1998) Coordinated release of acylation stimulating protein and triacylglycerol clearance by human adipose tissue in vivo in the postprandial period. Journal of Lipid Research 39, 884-891.

Samra JS, Frayn KN, Giddings JA, Clark ML \& Macdonald IA (1995) Modification and validation of a commercially available portable detector for measurement of adipose tissue blood flow. Clinical Physiology 15, 241-248.

Samra JS, Simpson EJ, Clark ML, Forster CD, Humphreys SM, Macdonald IA \& Frayn KN (1996) Effects of epinephrine infusion on adipose tissue: interactions between blood flow and lipid metabolism. American Journal of Physiology 271, E834-E839.

Simonsen L, Bülow J, Astrup A, Madsen J \& Christensen NJ (1990) Diet-induced changes in subcutaneous adipose tissue blood flow in man: effect of $\beta$-adrenoceptor inhibition. Acta Physiologica Scandinavica 139, 341-346.

Simonsen L, Bülow J \& Madsen J (1994) Adipose tissue metabolism in humans determined by vein catheterization and microdialysis techniques. American Journal of Physiology 266, E357-E365.

Sniderman AD \& Cianflone K (1997) The adipsinacylation-stimulating protein pathway and microenvironmental metabolic regulation. World Review of Nutrition and Dietetics 80, 44-81.

Sniderman AD, Cianflone K, Summers LKM, Fielding BA \& Frayn KN (1997) The acylation-stimulating protein pathway and regulation of postprandial metabolism. Proceedings of the Nutrition Society 56, 703-712.

Summers LKM, Arner P, Ilic V, Clark ML, Humphreys SM \& Frayn KN (1998) Adipose tissue metabolism in the postprandial period: microdialysis and arteriovenous techniques compared. American Journal of Physiology 274, E651-E655.

Summers LKM, Samra JS, Humphreys SM, Morris RJ \& Frayn KN (1996) Subcutaneous abdominal adipose tissue blood flow: variation within and between subjects and relationship to obesity. Clinical Science 91, 679-683.

Taylor R, Husband DJ, Marshall SM, Tunbridge WMG \& Alberti KGMM (1984) Adipocyte insulin binding and insulin sensitivity in 'brittle' diabetes. Diabetologia 27, 441-446.

Taylor R, Price TB, Katz LD, Shulman RG \& Shulman GI (1993) Direct measurement of change in muscle glycogen concentration after a mixed meal in normal subjects. American Journal of Physiology 265, E224-E229.

Vikman HL, Ranta S, Kiviluoto T \& Ohisalo JJ (1991) Different metabolic regulation by adenosine in omental and subcutaneous adipose tissue. Acta Physiologica Scandinavica 142, 405-410.

Wijnen JAG, van Baak MA, de Haan C, Struijker Boudier HAJ, Tan FS \& Van Bortel LMAB (1993) Beta-blockade and lipolysis during endurance exercise. European Journal of Clinical Pharmacology 45, 101-105.

Wolfe RR, Klein S, Carraro F \& Weber J-M (1990) Role of triglyceride-fatty acid cycle in controlling fat metabolism in humans during and after exercise. American Journal of Physiology 258, E382-E389.

Zierler KL (1961) Theory of the use of arteriovenous concentration differences for measuring metabolism in steady and non-steady states. Journal of Clinical Investigation 40, 2111-2125. 